\title{
强制換羽が産卵鷄におよぼす影響
}

\section{I. 春季に換羽を誘起した場合}

\author{
中沢稔・古田賢治* · 北野良一
}

滋賀県種鶏場 草津市

採卵を目的とした最近の養鵎経営では鶏を初産開始後 10〜12 か月で淘汰し更新している場合が多く，甚だし い場合では初産開始後 8 か月くらいで淘汰している例も あるようである。初産後 10～12 か月の間が産卵の高い 期間でこれ以上になると産卵の低下が大きくなるためで ある。卵の生産を低下させないで淘汰羽数を多くすれば 育雉羽数が多くなり, 養鶏経営にしめる鶏の育成費の割 合は大きくならざるを得ない。

一方，鶏が換羽を終ると一時的に産卵率が高くなり， 受精率，孵化率も高くなることを利用したいわゆる強制 換羽の技術が種卵採取の場合には実用化されている。

初産後 10〜12 か月以上を経過し産卵率が徐々に低下 している鶏を強制換羽させることにより経済的能力を高 めることができれば，種卵採取の場合だけでなく採卵養 鶏の場合でも強制換羽といら技術が実用化され得るので はないかと思われる。

しかし長期間にわたって採卵鶏を飼湌している場合に 強制換羽が産卵鵎の能力におよぼす影響についてはあま り知られていない。

本報告は初産後 12 か月以上経過した採卵䳕に強制換 羽処理を施し, その後 1 か年間飼養し強制換羽処理が産 卵鶏におよぼす影響につき検討したものである。

\section{材 料と方 法}

1964 年秋に孵化し初産後 12 か月以上経過した白色レ グホーン種 150 羽を 3 群に分け, 産卵鶏用単飼ケージ に收容して供試した。試験期間は 1966 年 4 月 1 日より 翌年 3 月 31 日までの 1 か年間である。試験開始前 3 か 月間の産卵数と自然換羽の有無により, 各群の産卵率と 換羽終了鵎鳥数がほぼ等しくなるように区分した。

強制換羽は 4 月 1 日より次のような方法で誘起せしめ た。第 1 群は 3 日間飼料飲水とも給与を停止し, 更に 2 日間は飲水の夕給与し飼料は給与しなかった。第 2 群 は 3 日間飼料飲水とも給与を停止した。第 3 群注無処理 で対照群とした。

昭和 42 年 11 月 11 日受付

* 現在 滋貿県農業改良課
市販産卵鶏用飼料を給与したが, 絶食期間終了直後に は 1 日 1 羽当り $20 \mathrm{~g}$ の飼料を給与し，以後 1 日 1 羽当

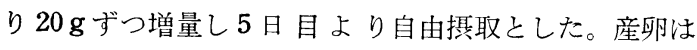
個体別，卵重は群別に記録し，飼料給与量から残量を差 し引いて飼料掑取量とした。試験開始より 8 月 31 日 までは自然日長で飼養したが，9～11 月は日長時間が 14 時間に，12〜1月は 15 時問に，2〜3 月は 16 時間にな るよう $30 \mathrm{~m}^{2}$ 当り $40 \mathrm{~W}$ 白熱電燈 4 個を地上約 $2 \mathrm{~m}$ の高 さから点燈した。

鶏の内外部寄生虫の駆除, ニューカッスル病の予防注 射は必要に応じて実施したが，実験期間中に発生した病 鶏の治療と淘汰は実施しなかった。

\section{結果}

換羽を誘起せしめるため飼料と飲水の給与を停止して 後 48 時間以内に産出された卵はほとえど正常卵であっ たが，48〜72 時間のものは約 $20 \%$ が正常卵で他は卵殻 膜に卵㲄が沈着していない軟卵であった。72 時間以後 の産卵法皆無であった。羽毛の脱落は換羽誘起処理開始 後 9 日目頃より盛えとなり 20 日頃まで続いた。

換羽誘起処理により第 1 群の 3 羽，第 2 群の 1 羽を除 いて他の鶏は全部換羽を起したが，換羽の進行状態には 個体差が著しかった。第 1 群と第 2 群ともに体の一部の 羽毛が換るいわゆる部分換羽にとどまる個体が多く，約 半数の鷂は主翼羽全部が換羽しないうちに産卵を回復し た。第 1 群の 3 羽と第 2 群の 1 羽は全く換羽を起さず一 時的に休産したのみであった。供試䳕のうちには $1 \sim 3$ 月に自然換羽したもの，換羽誘起処理を施したとき自然

表 1. 強制換羽誘起処理後の休産日数

Table 1. Days of nonlaying following forced molting

\begin{tabular}{|c|c|c|c|}
\hline & \multicolumn{3}{|c|}{ 休産日数 Days of nonlaying } \\
\hline & $\begin{array}{c}\text { 平 均 } \\
\mathrm{Av} \text {. }\end{array}$ & $\begin{array}{l}\text { 標準偏差 } \\
\text { S.D. }\end{array}$ & $\begin{array}{c}\text { 範 } \text { Range } \\
\text { Ran }\end{array}$ \\
\hline 第 1 群 Group 1 & 29.6 & 14.1 & $11 \sim 74$ \\
\hline 第 2 群 Group 2 & 31.7 & 18.9 & $9 \sim 73$ \\
\hline
\end{tabular}



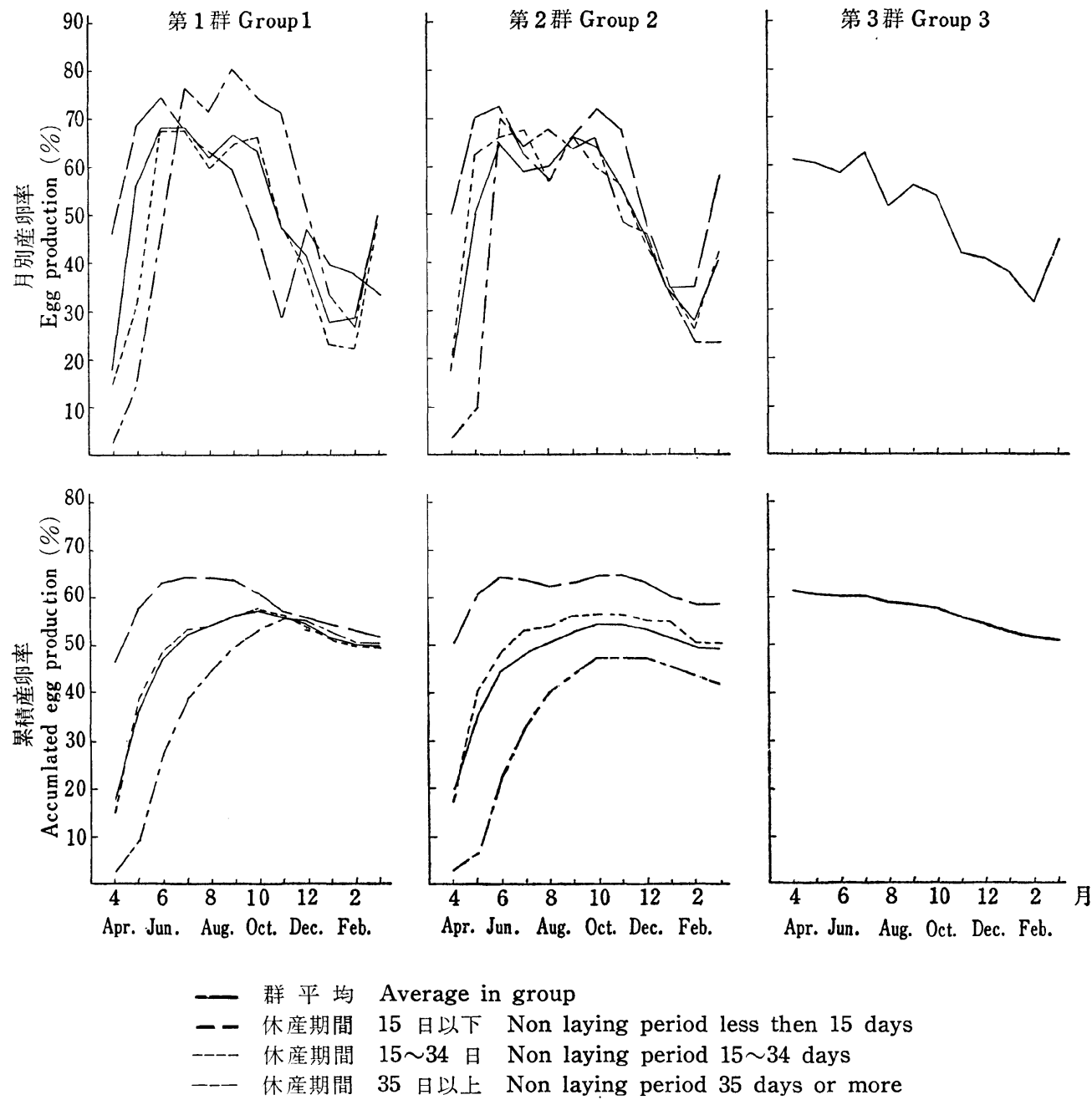

図 1. 月別産卵率之累積産卵率

Fig. 1. Percent of egg production per month and accumlated egg production

換羽をしかけていたもの，換羽はしていないが 15 日以 上休産しているものが各群に含まれていたが，これらの 鶏も換羽誘起処理により全部換羽を起した。表 1 に換羽 誘起処理により産卵を中止してから産卵を回復するまで の休産日数を示す。平均休産口数は第 1 群, 第 2 群とも に約 1 か月であったが，9１1 日の休産で産卵を回復し たものもあった。

強制換羽誘起処理を施してから産卵を開始するまでの 休産日数が 15 日未満のもの，15〜34 日のもの，35 日以 上のものに分けて各群の月別産卵率と累積産卵率を図 1 に示す。強制換羽誘起処理を施しても全く換羽を起さな かった鵎の記録は除外した。第 1 群の月別産卵率が第 3 群より高くなったのは 6〜10 月で換羽誘起処理後 3〜7
か月間であった。第 2 群の月別産卵率が第 3 群より高く なったのは 6〜12月で処理後 3〜9 か月間であった。換 羽誘起処理を施した後 1 ～2 か月鏟卵が低下するから この期間の累積産卵率は第 3 群より高くない。換羽誘起 処理後の休産日数が短かいものほど累積産卵率は高い傾 向を示し，第 1 群の休産日数 15 日未満のものの $6 \sim 10$ 月の累積産卵率は第 3 群より高かったが, 11 月以後では ほとえど差がなかった。第 2 群の休産日数 15 日未満の ものの累積産卵率は第 3 群より高かったが, 群平均で比 較すると 11 月以後は差がなかった。換羽誘起処理を施 したとき換羽を起さなかった鶏の試験期間中の産卵注高 くなく, 第 1 群の 3 羽のうち 2 羽が 202 , 115 卵で 1 羽は 試験期間中に獘死し，第 2 群の 1 羽は 163 卵であった。 
表 2. 試験期䦗前 1 か年と試験期間の産卵率および平均卵重

Table 2. Percent of egg production in pre-experimental and the experimental period and average egg weight.

\begin{tabular}{|c|c|c|c|c|c|}
\hline & \multirow[b]{2}{*}{$\begin{array}{c}\text { 強制換羽誘起処理による休産日数 } \\
\text { No. of days of nonlaying } \\
\text { following forced molting }\end{array}$} & \multirow[b]{2}{*}{$\begin{array}{l}\text { 羽 数 } \\
\text { No. of } \\
\text { hen }\end{array}$} & \multicolumn{2}{|c|}{ Percent of egg production } & \multirow[b]{2}{*}{$\begin{array}{l}\text { 試験期閒の } \\
\text { 平均卵重 } \\
\text { Av. egg wt. (g) } \\
\text { in exptl. period }\end{array}$} \\
\hline & & & 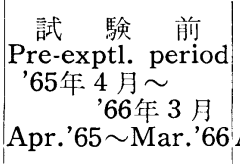 & $\begin{array}{c}\text { 試 験 期 閏 } \\
\text { Exptl. period } \\
\text { '66年 } 4 \text { 月〜 } \\
\text { '67年 } 3 \text { 月 } \\
\text { Apr.'66 Mar.' } 67\end{array}$ & \\
\hline 第 1 群 Group 1 & $\begin{array}{ll}15 \text { 日未満 } & \text { Less than } 15 \text { days } \\
15 \sim 34 \text { 日 } & 15 \sim 34 \text { days } \\
35 \text { 日以上 } & 35 \text { days or more } \\
\text { 平 均 Average }\end{array}$ & $\begin{array}{r}8 \\
35 \\
4 \\
47\end{array}$ & $\begin{array}{l}64.5 \\
63.9 \\
62.8 \\
64.3\end{array}$ & $\begin{array}{l}51.8 \\
49.4 \\
50.8 \\
49.9\end{array}$ & 57.5 \\
\hline 第 2 群 Group 2 & $\begin{array}{ll}15 \text { 日未満 } & \text { Less than } 15 \text { days } \\
15 \sim 34 \text { 日 } & 15 \sim 34 \text { days } \\
35 \text { 日以上 } & 35 \text { days or more } \\
\text { 平 均 Average }\end{array}$ & $\begin{array}{l}10 \\
27 \\
12 \\
49\end{array}$ & $\begin{array}{l}65.0 \\
60.8 \\
61.0 \\
62.0\end{array}$ & $\begin{array}{l}58.4 \\
50.3 \\
42.1 \\
49.1\end{array}$ & 57.9 \\
\hline 第 3 群 Group 3 & 平均 Average & 50 & 60.9 & 50.8 & 58.2 \\
\hline
\end{tabular}

表 3. 飼料掑取量 ( $\mathrm{g} /$ 羽/日), 飼料要求率, 平均体重および生存率

Table 3. Feed consumption (g/hen/day), feed conversion, average body weight and viability

\begin{tabular}{|c|c|c|c|c|c|}
\hline & & $\begin{array}{c}\text { 飼 料 } \\
\text { 摂取量 } \\
\text { Feed } \\
\text { consump. }\end{array}$ & $\begin{array}{c}\text { 飼 料 } \\
\text { 要求率 } \\
\text { Feed } \\
\text { conver. }\end{array}$ & $\begin{array}{c}\text { 平均体重 } \\
\text { Av. } \\
\text { body wt. }\end{array}$ & $\begin{array}{l}\text { 生存菹 } \\
\text { viability }\end{array}$ \\
\hline 第 1 群 & Group 1 & $102.9^{g}$ & 3.59 & $1873^{g}$ & $88.0 \%$ \\
\hline 第 2 群 & Group 2 & 103.3 & 3.64 & 1874 & 90.0 \\
\hline 第 3 群 & Group 3 & 102.4 & 3.47 & 1846 & 84.0 \\
\hline
\end{tabular}

各群の試験前 1 か年の産甽率之試験期間中の産卵率を 表 2 に示す。初産開始後 2 年目の産卵数は 1 年目の産卵 数より 10〜20\% 低下するといわれているが，本試験の 場合群平均で第 1 群が $22.4 \%$ ，第 2 群が $20.1 \%$ 低下し ていて，第 3 群の $16.6 \%$ より低下が大きかった。平均 卵重については群間に差がなかった。

飼料提取量, 飼料要求率, 試験終了時の平均体重およ び生存率を表 3 に示す。飼料掑取量は群間に差がなかっ た。換羽を誘起したことにより第 1 群は平均 $280 \mathrm{~g}$ ，第 2 群は $180 \mathrm{~g}$ の体重の減少がみられ，その回復に 6 9 週を必要とした。試験終了時の平均体重は処理群がやや 大きかった。整死鵎の発生は群による差はなく，また群 によって特定の疾病が多発することはなかった。

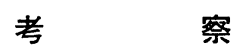

米国においては晚春か初夏に強制換羽を誘起させ, 卵
価の高い秋に卵の生産を高める技術は，養鵎業者の閥で 相当以前から実施されていたようである11。此倠䳕の自然 換羽は羽毛がある程度古くなったときに卵巣機能の低下 により起るので2,3)，人為的に換羽を誘起させるには絶食 や絶水によって雌鷄を休産に導くことが有効で, 古くか ら実用的に行なわれてきた。600日齢にもなる䳕の産卵 を完全に停止させるためには季節に関係なく，2 日間の 飼料と飲水の給与停止と,引続いて 7 日間の飼料給与の 停止が必要という4)。秋季に換羽を誘起するため 3.5 日 間飼料と飲水の給与を停止したが，品種間交配種や重種 では完全な換羽を誘起できなかったと報告らされてい る。わが国で種卵採取を目的として秋季に経験的に実施 されている強制換羽の方法は本試験と同じ程度の処理で ある。本試験のごとく春季に強制換羽誘起処理を施す場 合は換羽誘起が秋季より困難であると考えられ，全部の 鶏に完全な換羽をさせるには飼料と飲水の給与停止期閒 を本試験の場合より延長する必要があると思われる。

LEN et $a l^{5}$ 治制換羽誘起処理後 7 か月間の産卵を調 査し, 換羽鶏群の産卵が $12 \%$ 高く, 7 か月以後もこの 傾向が続いたと報告している。本試験の結果と比較する と, 換羽処理䳕群の処理後の産卵率注最高 $70 \%$ 程度で 本試験と変らないが, LEN et al の試験では対照䳕群で ある未処理䳕群の産卵染は常に $50 \%$ 以下であったため 換羽処理鷄群の産卵率との差が大きくなったのであら う。また換羽誘起処理を秋季に実施しているので，処理 後 7〜8 か月の産卵の低下与る頃が 4 5 月の産卵に適 した季節にあたったため，産卵低下が少なかったことが 
本試験と異なる結果となった主な理由と考えられる。 NOLES $^{4)}$ 治強制換羽誘起後 7〜8 か月の 産卵を調査し, 強制換羽は産卵数を增加させることはなく，その経済的 な効果注産卵の高いときに卵価が高ければ期待できると 報告している。本試験の場合，強制換羽を誘起してから 2 か月を経過すると産卵の上昇が著しく, 以後 5 ～７か月 は対照群より産卵率が高かった。しかし強制換羽を誘起 した後 2 か月問は産卵が低下するため第 2 群の休産期間 15 日未満の鶏群以外の累積産卵率は第 3 群より高くな らなかった。第 2 群の休産期閒 15 日未満のむのの累積 産卵率は第 3 群より高くなったが, 羽数は 10 羽で換羽 誘起処理鶏の $10 \%$ に過ぎなかった。群平均の累積産卵 率では第 1 群が 11 月と 12 月に約 $1 \%$ 第 3 群より高かっ た以外は第 3 群より低く, 第 2 群は常に第 3 群より低 かった。このことから本試験の場合でも 6 月から 10〜12 月までの卵価が高くないと経済効果にそしいといえる。

換羽誘起のための飼料給与停止期間が長ければ，産卵 の低下が大きいが換羽終了後の産卵がより高くなるとも 報告"さされている。本試験においては群平均について比 較与れば 5〜9 月の産卵注第 1 群が第 2 群より高かっ た。

強制換羽処理の効果としてこのほか飼料効率の改 善4),5)，卵殼 が厚くなること文,5),6)，卵質の改善4), (5,6), 卵重の増加 ${ }^{1)}$ などが知られているが，本試験において 飼料要求率, 卵重については換羽処理群と対照群に差が 認められなかった。

採卵鵎に強制換羽処理を施しても 1 羽当りの年間の産 卵数が増加することはあまり期待できず，鶏の経済能力 におよぼす効果洼著しいものではない。また換羽処理後 8～9 か月を経過すると産卵の低下も大きくなり，強制 換卵処理後 1 か年間の産卵率は $50 \%$ 程度であるから， 採卵鶏に強制換羽処理を施した後長期間にわたって飼養 する方法は, 初産後 10１2 か月で淘汰更新していく方 法と較べ経済的に有利な方法とはいえないだろう。

\section{要約}

鷄の孵化の盛えな季節に種卵の採取を高めるためいわ ゆる強制換羽の技術が実用化されている。初産後 1 か年 以上を経過し産卵の低下した採卵鷄に強制換羽処理を施 し，産卵などの経済的能力におよぼす影響につき検討し た。
採卵を目的としてケージにて飼養されている初産後 1 か年以上経過した白色レグホーン種 150 羽に強制換羽を 誘起せしめた。換羽は 1966 年 4 月 1 日から次のように して誘起した。第 1 群は 3 月間飼料と飲水の給与を停止 し更に 2 日間は飲水のみを給与した。第 2 群は 3 日間飼 料と飲水の給与を停止し, 第 3 群は無処理で対照群とし た。

結果の大要は次のごとくであった。

1）換羽誘起処理を施して 72 洔間経過主ると産卵法 中止し, 羽毛の脱落は処理後 9 日目頃より盛えになり 20 日頃をで続いた。換羽の状態は第 1 群，第 2 群ともに体 の一部の羽毛が換るいわゆる部分換羽にとどまった個体 が多く, 約半数の鵎は主翼羽全部が換羽しないうちに産 卵を回復した。換羽誘起処理による平均休産日数は約 1 か月で第 1 群と第 2 群との間に差は涊められなかった。

2）換羽誘起処理後 3 9 加月の産卵率忹第 1 群亡第 2 群が第 3 群より高かった。しかし累積産卵率では処理 後 7 か月までは第 3 群が高く，8 か月以後はほぼ等しく なり，換羽処理を施したことにより 1 羽当りの年間の産 卵数が多くなることはなかった。また第 1 群, 第 2 群と もに換羽誘起処理後の休産期間方短かいものほど産卵率 が高い傾向がみられた。

3）飼料損取量には群間に差がなく, 強制換羽処理に より飼料要求率が改善されることはなかった。各群の平 均卵重についても同様であった。

4）強制換羽処理が産卵鶏におよぼす経済的效果は大 きなものではない。強制換羽処理後の産卵が高くなって いる期間の卵価が高い場合は経済的に有利となるである う。強制換羽処理をすることにより経済能力を高め, 長 期間飼養しようとする方法は必ずしも経済的に有利とは 考えられない。

\section{文献}

1) Berg, L.R. and G.E. Bearse: Poultry Sci., 26, 414, 1947.

2) Tanabe, Y., K. Himeno and H. Nozaki: Endocrinology, 61, 661. 1957.

3）田名部雄一・葛城俊松：農技研報，G 21，49, 1962.

4) Noles, R.K.: Poultry Sci., 45, 50, 1966.

5) Len, R.E., H. Abplanalp and E.A. Johnson: Poultry Sci., 43, 638, 1964.

6) Hansen, R.S.: Poultry Sci., 39, 1257, 1960. 


\title{
Studies on the Forced Molting in Layers
}

I. Effects of the Forced Molting in Spring on the Performance of the Layer

\author{
Minoru Nakazawa, Kenji Furuta and Ryoichi Kitano \\ Shiga Prefectural Poultry Breeding Station, Kusatsu-shi, Shiga-ken
}

For the production of hatching eggs, forcing molt in breeders has been a popular method used. But the effect of the forced molting on the performance of layers has not been clearly demonstrated. This paper deals with the performance of the layers following the molt which was induced in spring.

One hundred and fifty White Leghorn hens which had been laying eggs more than one year were divided into three groups. In Group 1, birds were deprived of both feed and water for 3 days and of feed for succeeding 2 days. In Group 2, birds were deprived of both feed and water for 3 days. In Group 3, no treatment was done. Experiments were started on April 1, 1966. Egg layings and egg weights were recorded for one year following the onset of the treatment. Feed conversion was also checked.

Within 72 hours after starvation, birds stopped laying, and from 9 to 20 days feathers fell down severely. However, half of the birds treated did not show full molting. Egg production reinitiated on about 30 days after treatment. No significant difference was observed in the days required for the reinitiation of egg laying. It seems that the shorter the nonlaying period the higher the rate of egg production in 3 months after treatment.

The percentage of the egg production in the period of 3-9 months after treatment was higher in Groups 1 and 2 than in Group 3. However, the total number of eggs produced did not differ significantly.

The egg weight and the feed conversion were not affected by the forced molting.

Forcing molt in spring may not be economically advantageous unless egg price is expected to be high during the period of 3-9 months after the molt. (Japan. Poultry Sci, 5, 131, 1968). 